\title{
BENTUK IMPLIKATUR PERCAKAPAN PADA UNGKAPAN PEMBERLAKUAN KURIKULUM 2013 DI SMK N 8 SURAKARTA
}

\author{
Hari Prayogo dan Atiqa Sabardila \\ Program Studi Pendidikan Bahasa Indonesia \\ Universitas Muhammadiyah Surakarta \\ Jl. A. Yani Tromol Pos 1 Pabelan, Kartasura, Surakarta (57127) \\ Email: Prayogo2c120font@gmail.com
}

\begin{abstract}
This research aims to describe the form of implicatures found in conversations between students and teachers based on the implementation of the 2013 Curicullum enactment in SMK N 8 Surakarta. This research is qualitative type which also uses the descriptive method within it. The data sources of this research are the conversations between students and teachers. The samples of this research are expression of the 2013 curicullum 2013's enactments in SMK N 8 Surakarta. The data collecting technique in this research is attentive method followed by quotation method. The analysis technique is the selection elements determined by the selection of pragmatic. Also, this research uses an advancing step that is connect-compare with the standard variety. The results can be clarified in eight types. They are (1) implicature with the intention to explain, (2) implicature with the intention of complaining, (3) implicature with intention of asking, (4) implicature with intention to satirize, (5) implicature with the intention of the prediction, (6) implicature with the intention of the skepticism (7) implicature with the intention of the are a speeches and (8) implicature with the intention of the appealing.
\end{abstract}

Keywords: Implicature, the 2013 curiculum, students-teachers conversations, SMK N 8 Surakarta.

\begin{abstract}
ABSTRAK
Penelitian ini bertujuan untuk mendeskripsikan bentuk implikatur percakapan pada ungkapan pemberlakuan Kurikulum 2013 di SMK N 8 Surakarta. Jenis penelititan ini adalah penelitian kualitatif yang menggunakan metode deskripsi. Sumber data dalam penelitian ini adalah percakapan yang dilakukan guru terkait dengan pemberlakuan Kurikulum 2013. Contoh penelitian yaitu ungkapan pemberlakuan kurikulum 2013 di SMK N 8 Surakarta. Teknik pengumpulan contoh menggunakan metode simak yang dilanjutkan dengan teknik catat. Teknik analisis menggunakan teknik pilah unsur penentu daya pilah pragmatis dan menggunakan teknik lanjutan yaitu teknik hubung banding menyamakan dengan alat penyamaan: standar penyamaan atau pembaku. Hasil penelitian bentuk implikatur percakapan pada ungkapan pemberlakuan Kurikulum 2013 di SMK N 8 Surakarta dapat diklasifikasikan menjadi 8 bentuk, yakni: (1) Bentuk implikatur yang mempunyai maksud memberitahu,(2) Bentuk implikatur yang mempunyai maksud mengeluh, (3) Bentuk implikatur yang mempunyai maksud menanya, (4) Bentuk implikatur yang mempunyai maksud menyindir, (5) Bentuk implikatur yang mempunyai maksud dugaan, (6) Bentuk implikatur yang mempunyai maksud keraguan, (7) Bentuk implikatur yang mempunyai maksud kesedihan, dan (8) Bentuk implikatur yang mempunyai maksud memohon.
\end{abstract}

Kata Kunci: Implikatur, kurikulum 2013, tuturan guru-siswa, SMK N 8 Surakarta. 


\section{PENDAHULUAN}

Percakapan yang baik setidaknya dilakukan oleh dua orang atau lebih. Dalam hal ini ada penutur dan mitra tutur sehingga percakapan bisa berjalan dengan baik dan bisa menghasilkan sebuah tujuan percakapan. Di dalam sebuah percakapan tentunya terdapat berbagai wacana yang muncul. Menganalisis wacana diarahkan dengan pendekatan pragmatis untuk memahami pemakaian bahasa. Konsep yang berkaitan dengan konteks wacana yang diperlukan dalam analisis wacana, satu diantaranya adalah implikatur.

Pemberlakuan kurikulum 2013 yang cenderung mendadak membuat para pengguna, baik guru maupun siswa agak sedikit kebingungan karena kurikulum 2013 lebih kompleks. Hal demikianlah yang membuat para guru harus bekerja keras untuk mempelajari kurikulum baru ini, berbagai tanggapan pun muncul dari para guru. Akan tetapi, keputusan sudah ditentutukan hal yang bisa dilakukan yaitu menjalankannya.

Sama halnya dengan kondisi yang berada di SMK N 8 Surakarta, pemberlakuan kurikulum 2013 dirasa sangat cepat dan kurang persiapan. Berbeda dengan sekolah lainnya, SMK N 8 Surakarta adalah sekolah menengah kejuruan yang memiliki bidang keahlian seni pertunjukan yang terdiri dari empat program keahlian, yaitu seni karawitan, seni pedalangan, seni tari, dan seni musik. Tak hayal ada tanggapan beragam dari para guru yang berada di SMK N 8 Surakarta terkait pemberlakuan kurikulum 2013.

Adanya berbagai tanggapan tentang pemberlakuan kurikulum 2013 muncul dari para guru, khususnya guru di SMK N 8 Surakarta. Hal inilah ingin diteliti oleh peneliti bahwa peneliti melihat adanya persoalan dalam pemberlakuan kurikulum 2013 sehingga peneliti ingin menguak dari segi bahasa atau ungkapan yang dituturkan oleh para guru khususnya dari segi kajian implikaturnya.

Penelitian ini mempunyai solusi yang akan dipecahkan dari rumusan masalah. Permasalahan yang akan dibahas yaitu bentuk dan maksud implikatur percakapan pada ungkapan pemberlakuan Kurikulum 2013 di SMK N 8 Surakarta. Lebih lanjut penelitian ini bertujuan untuk mendeskripsikan bentuk dan maksud implikatur percakapan pada ungkapan pemberlakuan Kurikulum 2013 di SMK N 8 Surakarta.

Implikatur yang menjadi kajian dalam penelitian ini mempunyai banyak teori. Keberadaan implikatur muncul salah satunya akibat teori yang dikemukakan oleh Grice. Selain Grice, ada pula tokoh dalam negeri yang memberikan teorinya tentang implikatur. Wijana dan Rohmadi (2009:4) menjelaskan pragmatik adalah cabang ilmu bahasa yang mempelajari struktur bahasa secara eksternal, yaitu bagaimana suatu kebahasaan itu digunakan dalam komunikasi. Tidak hanya Grice yang mengemukakan teorinya tentang implikatur. Ada pula Yule. Yule (2006:34) mendefinisikan beberapa pengertian pragmatik. Salah satunya adalah sebagai berikut. Pragmatik adalah studi tentang makna yang disampaikan oleh penutur (penulis) dan ditafsirkan oleh pendengar (pembaca). Sebagai akibatnya studi ini lebih banyak berhubungan dengan analisis tentang apa yang dimaksudkan orang dengan tuturan-tuturanya dari pada dengan makna terpisah dari kata atau frasa yang digunakan dalam tuturan itu sendiri. Pragmatik studi tentang maksud penutur.

\section{METODE PENELITIAN}

Jenis penelitian yang digunakan dalam penelitian ini adalah penelitian kualitatif. Penelitian kualitatif adalah metode penelitian yang berlandaskan filsafat postpositivisme, yang digunakan untuk meneliti pada kondisi objek yang alamiah (sebagai lawannya adalah eksperimen), yaitu peneliti adalah sebagai instrumen kunci, teknik pengumpulan contoh dilakukan secara triangulasi (gabungan), analisis contoh bersifat induktif/ kualitatif, dan hasil penelitian kualitatif ini lebih menekankan makna dari generalisasi (Sugiyono, 2012:9). 
Sebagai ilmu empiris yang objeknya itu bahasa, contoh adalah mutlak perlu sehingga perlu disediakan dan penyediaannya pun harus secukupnya, dalam arti dimungkinkan betul-betul untuk dianalisis segala seginya yang relevan sehingga setelah dianalisis selesai dilakukan diperoleh hasil yang berupa pemahaman terhadap objeknya itu relatif lengkap dan utuh (Sudaryanto, 2015:216). Contoh dalam penelitian ini berupa ungkapan pemberlakuan kurikulum 2013 di SMK N 8 Surakarta. Selanjutnya, sumber contoh dalam penelitian ini adalah ungkapan yang dilakukan guru terkait pemberlakuan Kurikulum 2013. Narasumber yang diambil yaitu guru SMK N 8 Surakarta. Teknik penyedian contoh yang digunakan dalam penelitian ini adalah teknik simak. Disebut "metode simak" atau "penyimakan" karena memang berupa penyimakan: dilakukan dengan menyimak, yaitu menyimak penggunaan bahasa. ini dapat disejajarkan dengan "metode pengamatan" atau "metode observasi" dalam ilmu sosial, khususnya antropologi (Sudaryanto, 2015:203).

Pada praktiknya penyimakan atau metode simak itu diwujudkan dengan penyadapan. Kegiatan menyadap itu dilakukan pertama-tama dengan berpartisipasi sambil menyimak berpartisipasi dalam pembicaraan dan menyimak pembicaraan, teknik ini dapat disebut teknik simak libat cakap atau SLC. Ketika teknik pertama digunakan, sekaligus dapat dilakukan pula perekaman dengan tape atau recorder tertentu sebagai alatnya. Perekaman terhadap tuturan itu dipandang sebagai teknik lanjutan yang ketiga, dan disebut teknik rekam. Di samping perekaman, dapat pula dilakukan pencatatan pada kartu contoh yang segera dilanjutkan dengan klasifikasi. Pada teknik ini pencatatan contoh bergantung kepada jenis objek sasarannya dan tujuannya, yaitu transkripsi ortografis, fonemis, atau fonetis. Pencatatan semacam itudapat pula dipandang sebagai teknik lanjutan keempat dan disebut teknik catat (Sudaryanto, 2015:203206).

Tahapan analisis contoh merupakan tahapan yang sangat menentukan karena pada tahapan ini kaidah-kaidah yang mengatur keberadaan objek penelitian harus sudah diperoleh. Penemuan kaidah-kaidah tersebut merupakan inti dari sebuah aktivitas ilmiah yang disebut penelitian, betapa pun sederhananya kaidah yang ditemukan tersebut. Dari berbagai metode yang ada diantaranya yaitu metode padan, alat penentunya di luar, terlepas, dan tidak menjadi bagian dari bahasa (langue) yang bersangkutan. Metode ini dapat dibedakan menjadi paling tidak menjadi lima sub-jenis berdasarkan macam alat penentu yang dimaksud yaitu (1) Referensial alat penentunya referen, (2) Fonetis Artikulatoris alat penentunya organ wicara, (3) Translasional alat penentunya bahasa lain, (4) Ortografis alat penentunya tulisan, dan (5) Pragmatis alat penentunya mitra wicara (Sudaryanto, 2015:15-18).

Di dalam metode padan terdapat dua teknik, yaitu teknik dasar dan teknik lanjutan. Teknik dasar yang dimaksud disebut "teknik pilah unsur penentu" atau teknik PUP. Adapun alatnya ialah daya pilah yang bersifat mental yang dimilki oleh penelitinya sesuai dengan jenis penentu yang akan dipilah-pilahkan. Selanjutnya, teknik yang kedua adalah teknik lanjutan, teknik ini dibedakan tiga sub-jenis yaitu (1) teknik hubung banding menyamakan (atau teknik HBS), (2) teknik hubung banding memperbedakan (atau teknik HBB), dan (3) teknik hubung banding menyamakan hal pokok (atau teknik HBSP). Yang sebagai alatnya masing-masing menggunakan daya banding menyamakan, daya banding memperbedakan, dan daya banding menyamakan hal pokok (Sudaryanto, 2015:25-32).

Teknik analisis contoh dalam penelitian ini menggunakan metode padan pragmatis dengan alat penentunya yaitu mitra wicara sehingga pada tujuan ini menggunakan teknik dasar yaitu teknik pilah unsur penentu daya pilah pragmatis dan menggunakan teknik lanjutan yaitu teknik hubung banding menyamakan dengan alat penyamaan: standar penyamaan atau pembaku. Dalam teknik pengumpulan contoh, trianggulasi diartikan sebagai teknik pengumpulan contoh yang bersifat menggabungkan dari berbagai teknik pengumpulan contoh dan sumber contoh 
yang telah ada. Pengumpulan contoh dilakukan dengan trianggulasi, maksud dan tujuannya yaitu untuk menguji kredibilitas contoh, mengecek kredibilitas contoh dengan berbagai teknik pengumpulan contoh dan berbagai sumber contoh. Trianggulasi sumber, berarti pengumpulan contoh dengan mendapatkan contoh dari sumber yang berbeda-beda dengan teknik yang sama (Sugiyono, 2012:241).

\section{HASIL DAN PEMBAHASAN}

Berdasarkan temuan-temuan didapatkan bentuk implikatur percakapan pada ungkapan pemberlakuan Kurikulum 2013 di SMK N 8 Surakarta. selanjutnya, temuan-temuan tersebut akan dideskripsikan berikut ini.

\section{Bentuk Implikatur yang Mempunyai Maksud Memberitahu Pelaksanaan Kurikulum 2013}

Memberitahu merupakan salah satu jenis implikatur percakapan yang ditemukan pada ungkapan pemberlakuan Kurikulum 2013 di SMK N 8 Surakarta. Memberitahu adalah ungkapan yang diucapkan oleh penutur kepada mitra tutur untuk menginformasikan suatu hal. Menyatakan pemberitahuan termasuk ke dalam tindak tutur representatif atau asertif. Contoh yang menunjukkan implikatur percakapan yang mempunyai maksud memberitahu yaitu sebagai berikut.

Berikut percakapan antara peneliti dan guru Matematika di SMK N 8 Surakarta, Kamis, 18 Februari 2016.

"Iya, sebenarnya secara umum kurikulum 2013 itu bagus, artinya mengaktifkan siswa, terus langkah-langkah itu tidak dari dulu mendoktrinkan nggak, tetapikan siswa menemukan sendiri."

Konteks percakapan contoh (1) di atas yaitu antara peneliti dengan guru Matematika. Percakapan yang dilakukan didesain dengan metode wawancara. Konteks tuturan yang terbentuk adalah guru menganggap bahwa pemberlakuan Kurikulum 2013 itu lebih bagus dari kurikulum yang lama, yaitu KTSP. Menurut guru tersebut, Kurikulum 2013 dapat mengaktifkan siswa serta langkah-langkah dalam pembelajarannya tidak mendoktrin siswa, tetapi siswa menemukan sendiri tema yang akan dibahas dalam pembelajaran. Konteks tuturan di atas terbentuk dari pertanyaan yang diajukan oleh peneliti terhadap guru. Implikatur yang dihasilkan dari tuturan tersebut yaitu guru memberitahu pada peneliti bahwa kurikulum 2013 lebih bagus dari kurikulum KTSP dari segi pembelajarannya. Contoh (1) di atas merupakan bentuk implikatur memberitahu pelaksanaan Kurikulum 2013. Penelitian ini memiliki kesamaan dan perbedaan dengan penelitian terdahulu yaitu penelitian Risalatul Umami (2013) berjudul "Implikatur Percakapan dalam Wacana Pojok pada Djaka Lodang Edisi JanuariJuni Tahun 2013". Hasil penelitian ini disimpulkan bahwa : (1) Implikatur Dhat Nyeng edisi Januari 2013 hingga Juni 2013 menggunakan implikatur sebagai sarana untuk menyatakan sesuatu, menyindir, menanggapi, menghimbau, mengajak, dan mengkritik. Perbedaan terjadi pada objek yang dikaji pada kedua penelitian, penelitian ini mengkaji objek tuturan ungkapan pemberlakuan Kurikulum 2013 sedangkan penelitian Umami mengkaji objek wacana pojok pada Djaka Lodang.

Percakapan antara peneliti dan guru Bahasa Indonesia di SMK N 8 Surakarta, Jumat, 22 April 2016.

“Artinya sebagai seorang pendidik dengan mengetahui esensi Kurikulum 2013 itu setuju." 
Pada contoh (2) konteks percakapan yang terjadi antara peneliti dengan guru Bahasa Indonesia. Percakapan yang terjadi tentang pemberlakuan Kurikulum 2013 yang telah dilaksanakan di SMK N 8 Surakarta. pada percakapan tersebut diberitahukan bahwa guru tersebut melihat pemberlakuan kurikulum dari segi pendidik itu setuju. Guru tersebut menyebutkan bahwa kurikulum yang baru siswa diberi keleluasaan untuk mengeksplor diri. Pada contoh (2) yang menjadi alasan implikatur yaitu informasi yang disampaikan guru bahwa setuju atas pemberlakuan Kurikulum 2013 karena siswa dapat mengeksplor dan mengembangkan diri lebih luas. Contoh (2) di atas merupakan bentuk implikatur memberitahu pelaksanaan Kurikulum 2013. Penelitian ini memiliki kesamaan dan perbedaan dengan penelitian terdahulu yaitu penelitian Timur Sri Astami (2014) berjudul "Implikatur Percakapan dalam Film Nihonjin No Shiranai Nihongo". Hasil penelitian menunjukkan implikatur percakapan berupa permintaan, pertanyaan, dugaan, keraguan, kesedihan, sindiran, ejekan, perintah, fakta, dan ajakan terdapat pada film. Perbedaan terjadi pada objek yang dikaji pada kedua penelitian, penelitian ini mengkaji objek tuturan ungkapan pemberlakuan Kurikulum 2013 sedangkan penelitian Astami mengkaji objek Percakapan pada Film.

Berikut percakapan antara peneliti dan guru Bahasa Inggris di SMK N 8 Surakarta, Rabu, 04 Mei 2016.

"Yang KTSP dengan kurikulum 2013 itu ada beberapa perbedaanya yang paling kelihatan sekali yaitu tentang proses pembelajarannya."

Pada contoh (3) percakapan dilakukan peneliti dengan guru Bahasa Inggris. Konteks percakapan yang terjadi tentang perbedaan Kurikulum 2013 dengan KTSP. Percakapan menghasilkan sebuah informasi yang disampaikan guru berkaitan tentang perbedaan kurikulum. Informasi tersebut yaitu perbedaan yang paling kelihatan tentang Kurikulum 2013 dan KTSP pada bagian proses pembelajarannya. Proses pembelajaran KTSP menggunakan EEK sedangkan Kurikulum 2013 menggunakan 5M. Pada percakapan contoh (3) yang menjadi alasan masuk implikatur memberitahu adalah adanya informasi yang disampaikan oleh guru. Informasinya adalah proses pembelajaran yang terjadi pada Kurikulum 2013 dengan KTSP itu berbeda. Contoh (3) di atas merupakan bentuk implikatur memberitahu pelaksanaan Kurikulum 2013. Penelitian ini memiliki kesamaan dan perbedaan dengan penelitian terdahulu yaitu penelitian Risalatul Umami (2013) berjudul "Implikatur Percakapan dalam Wacana Pojok pada Djaka Lodang Edisi Januari-Juni Tahun 2013”. Hasil penelitian ini disimpulkan bahwa : (1) Implikatur Dhat Nyeng edisi Januari 2013 hingga Juni 2013 menggunakan implikatur sebagai sarana untuk menyatakan sesuatu, menyindir, menanggapi, menghimbau, mengajak, dan mengkritik. Perbedaan terjadi pada objek yang dikaji pada kedua penelitian, penelitian ini mengkaji objek tuturan ungkapan pemberlakuan Kurikulum 2013, sedangkan penelitian Umami mengkaji objek wacana pojok pada Djaka Lodang.

\section{Bentuk Implikatur yang Mempunyai Maksud Mengeluh Kendala Kurikulum 2013}

Berikut percakapan antara peneliti dan guru Matematika di SMK N 8 Surakarta, Kamis, 18 Februari 2016.

"Yang Matematika saya rasa kadang-kadang kurang menyasar, kalau di Matematika kendalanya mungkin di buku maka guru perlu membuat ini (LKS)."

Pada contoh (4) konteks percakapan yang terjadi masih tentang pemberlakuan Kurikulum 2013. Pada contoh (4) ini guru menyampaikan bahwa pada mata pelajaran matematika materi 
yang ada kadang-kadang kurang menyasar, kurang kompleks. Pada mata pelajaran Matematika kendala juga terjadi pada buku sehingga guru perlu membuat LKS tambahan. Contoh (4) yang menjadi alasan masuk implikatur mengeluh yaitu guru merasa materi yang ada di Matematika kurang menyasar. Apalagi kendala yang terjadi di matematika ada pada buku. Contoh (4) di atas merupakan bentuk implikatur mengeluh adanya berbagai kendala di Kurikulum 2013. Penelitian ini memiliki kesamaan dan perbedaan dengan penelitian terdahulu yaitu penelitian Timur Sri Astami (2014) berjudul "Implikatur Percakapan dalam Film Nihonjin No Shiranai Nihongo". Hasil penelitian menunjukkan implikatur percakapan berupa permintaan, pertanyaan, dugaan, keraguan, kesedihan, sindiran, ejekan, perintah, fakta, dan ajakan terdapat pada film. Perbedaan terjadi pada objek yang dikaji pada kedua penelitian, penelitian ini mengkaji objek tuturan ungkapan pemberlakuan Kurikulum 2013, sedangkan penelitian Astami mengkaji objek Percakapan pada Film.

Percakapan antara peneliti dan guru Bahasa Inggris di SMK N 8 Surakarta, Rabu, 04 Mei 2016.

"Kemudian, untuk kekurangannya masih ada lagi pelaksanaan belum diikuti kesiapan guru dan sarana prasarana pada tahun pertama."

Konteks percakapan pada contoh (5) mengemukakan kelanjutan dari contoh sebelumnya tentang kekurangan dan kelebihan Kurikulum 2013. Guru mengatakan bahwa selain kekurangan yang terjadi pada contoh sebelumnya ada juga selain itu yaitu belum diikutinya kesiapan guru dan sarana prasarana pada pelaksanaan Kurikulum 2013 di tahun pertama. Untuk tahun kedua persiapan tersebut sudah ada semisal adanya diklat, dan adanya buku paket buat siswa. Contoh (5) yang menjadi alasan masuk pada implikatur mengeluh yaitu munculnya keluhan guru terhadap pelaksanaan Kurikulum 2013 pada tahun pertama mengenai kesiapan guru dan sarana prasarana. Contoh (5) di atas merupakan bentuk implikatur mengeluh adanya berbagai kendala di Kurikulum 2013. Penelitian ini memiliki kesamaan dan perbedaan dengan penelitian terdahulu yaitu penelitian Risalatul Umami (2013) berjudul "Implikatur Percakapan dalam Wacana Pojok pada Djaka Lodang Edisi Januari-Juni Tahun 2013”. Hasil penelitian ini disimpulkan bahwa : (1) Implikatur Dhat Nyeng edisi Januari 2013 hingga Juni 2013 menggunakan implikatur sebagai sarana untuk menyatakan sesuatu, menyindir, menanggapi, menghimbau, mengajak, dan mengkritik. Perbedaan terjadi pada objek yang dikaji pada kedua penelitian, penelitian ini mengkaji objek tuturan ungkapan pemberlakuan Kurikulum 2013 sedangkan penelitian Umami mengkaji objek wacana pojok pada Djaka Lodang.

\section{Bentuk Implikatur yang Mempunyai Maksud Menanya Proses Kurikulum 2013}

Berikut percakapan antara peneliti dan guru Matematika di SMK N 8 Surakarta, Kamis, 18 Februari 2016.

"Walaupun yang SMA peminatan dan tambahan tetapi secara umum memang berbeda. Kenapa dipaksa sama? “

Konteks percakapan yang terjadi pada contoh (6) mengenai kekurangan dan kelebihan Kurikulum 2013 yang terjadi pada mata pelajaran Matematika. Pada percakapan di atas yang bahwa adanya perbedaan antara Matematika yang ada pada beberapa program keahlian seperti teknik, akuntansi, dan pariwisata. Pada Kurikulum 2013 semua program keahlian tersebut menerapkan materi yang sama sehingga menuai kritik dari guru yang bersangkutan yang notabene mengajar pada program keahlian pariwisata. Akhirnya, muncullah sebuah pertanyaan 
yang sangat tendensius dari guru tersebut "Kenapa dipaksa sama?". Pertanyaan tersebut yang ingin mendapat kejelasan dari pihak yang bersangkutan agar guru-guru yang berada pada program keahlian tersebut mengerti permasalahannya dibuat sama. Contoh (6) yang menjadi alasan masuk implikatur menanya karena adanya sebuah pertanyaan balik dari guru yang ingin mencari kejelasan tentang diberlakukannya kesamaan materi antara beberapa program keahlian. Dasar yang disampaikan guru adalah pada penerapan kurikulum KTSP materi antara program keahlian itu berbeda-beda dan memeliki kelebihan masing-masing. Apabila dibuat sedemikian, maka kelebihan-kelebihan yang ada akan secara tidak langsung dihilangkan. Contoh (6) di atas merupakan bentuk implikatur menanya balik tentang proses Kurikulum 2013. Penelitian ini memiliki kesamaan dan perbedaan dengan penelitian terdahulu yaitu penelitian Timur Sri Astami (2014) berjudul "Implikatur Percakapan dalam Film Nihonjin No Shiranai Nihongo". Hasil penelitian menunjukkan implikatur percakapan berupa permintaan, pertanyaan, dugaan, keraguan, kesedihan, sindiran, ejekan, perintah, fakta, dan ajakan terdapat pada film. Perbedaan terjadi pada objek yang dikaji pada kedua penelitian, penelitian ini mengkaji objek tuturan ungkapan pemberlakuan Kurikulum 2013, sedangkan penelitian Astami mengkaji objek Percakapan pada Film.

Percakapan antara peneliti dan guru Bahasa Indonesia di SMK N 8 Surakarta, Jumat, 22 April 2016.

"Dengan gambaran seperti itu, sekarang kita berfikir secara global, kira-kira bisakah lancar perjalanan Kurikulum 2013?”

Pada contoh (7) konteks percakapan yang terjadi mengenai pemberlakuan Kurikulum 2013. Percakapan diatas guru menyampaikan bahwa adanya pro dan kontra yang terjadi pada pelaksanaan Kurikulum 2013. Fasilitas yang kurang juga menjadi masalah yang dihadapi pada penerapan Kurikulum 2013. Pada percakapan tersebut kelancaran perjalan Kurikulum 2013 menjadi pertanyaan dari guru tersebut. Guru menganggap bahwa Kurikulum 2013 belum bisa sempurna diterapkan dengan adanya pro dan kontra serta fasilitas yang kurang memadai. Contoh (7) yang menjadi alasan masuk implikatur menanya yaitu pertanyaan yang muncul dari guru berkaitan dengan kelancaran Kurikulum 2013. Contoh (7) di atas merupakan bentuk implikatur menanya balik tentang proses Kurikulum 2013. Penelitian ini memiliki kesamaan dan perbedaan dengan penelitian terdahulu yaitu penelitian Risalatul Umami (2013) berjudul "Implikatur Percakapan dalam Wacana Pojok pada Djaka Lodang Edisi Januari-Juni Tahun 2013". Hasil penelitian ini disimpulkan bahwa: (1) Implikatur Dhat Nyeng edisi Januari 2013 hingga Juni 2013 menggunakan implikatur sebagai sarana untuk menyatakan sesuatu, menyindir, menanggapi, menghimbau, mengajak, dan mengkritik. Perbedaan terjadi pada objek yang dikaji pada kedua penelitian, penelitian ini mengkaji objek tuturan ungkapan pemberlakuan Kurikulum 2013 sedangkan penelitian Umami mengkaji objek wacana pojok pada Djaka Lodang.

\section{Bentuk Implikatur yang Mempunyai Maksud Menyindir Pelaksanaan Kurikulum 2013}

Percakapan antara peneliti dan guru Matematika di SMK N 8 Surakarta, Kamis, 18 Februari 2016.

"Cuma, ya itu tadi. Kalau guru-guru yang muda mengikutinya, bisa cepat, tapi kan tetap ada juga orang-orang yang sudah tetap konvensional itu kadang-kadang gak berubahnya.” 
Contoh (8) konteks percakapan yang terjadi mengenai perubahan yang terjadi setelah adanya perubahan kurikulum. Percakapan di atas guru menjelaskan bahwa pada perubahan mengharuskan guru untuk mengikuti prosedur yang mengharuskan untuk berbasis teknologi. Guru yang muda misalnya mengikuti dengan mudah, tetapi untuk guru yang senior merasa kesulitan untuk mengikutinya. Contoh (8) yang menjadi alasan masuk implikatur menyindir yaitu adanya tanggapan guru mengenai perubahan kurikulum yang harus diikuti dengan penerapan teknologi sehingga guru senior maupun junior harus bisa mengikuti. Contoh (8) di atas merupakan bentuk implikatur menyindir pelaksanaan Kurikulum 2013. Penelitian ini memiliki kesamaan dan perbedaan dengan penelitian terdahulu, yaitu penelitian Timur Sri Astami (2014) berjudul "Implikatur Percakapan dalam Film Nihonjin No Shiranai Nihongo". Hasil penelitian menunjukkan implikatur percakapan berupa permintaan, pertanyaan, dugaan, keraguan, kesedihan, sindiran, ejekan, perintah, fakta, dan ajakan terdapat pada film. Perbedaan terjadi pada objek yang dikaji pada kedua penelitian, penelitian ini mengkaji objek tuturan ungkapan pemberlakuan Kurikulum 2013, sedangkan penelitian Astami mengkaji objek Percakapan pada Film.

Percakapan antara peneliti dan guru Bahasa Indonesia di SMK N 8 Surakarta, Jumat, 22 April 2016.

"Menurut saya lho ya, saya itu kalau melihat kok hampir setiap pergantian pejabat tingkat pemerintahan dan itu berkaitan dengan Kemendikbud atau Kemendiknas katakanlah apapun istilahnya, itu berubah."

Konteks percakapan pada contoh (9) mengenai perbedaan antara Kurikulum 2013 dengan KTSP. Guru bersangkutan memaparkan pendapatnya bahwa dalam setiap perubahan pejabat di Kemendikbud, kurikulum juga mengalami perubahan. Perbedaan tentunya ada karena setiap kurikulum itu tentu memiliki kelebihan dan kekurangannya masing-masing. Contoh (9) yang menjadi alasan masuk implikatur menyindir yaitu guru menyampaikan ketidak sukaannya dengan pergantian kurikulum yang dilakukan ketika pejabat Kemendikbud berganti. Contoh (9) di atas merupakan bentuk implikatur menyindir pelaksanaan Kurikulum 2013. Penelitian ini memiliki kesamaan dan perbedaan dengan penelitian terdahulu yaitu penelitian Risalatul Umami (2013) berjudul "Implikatur Percakapan dalam Wacana Pojok pada Djaka Lodang Edisi Januari-Juni Tahun 2013". Hasil penelitian ini disimpulkan bahwa : (1) Implikatur Dhat Nyeng edisi Januari 2013 hingga Juni 2013 menggunakan implikatur sebagai sarana untuk menyatakan sesuatu, menyindir, menanggapi, menghimbau, mengajak, dan mengkritik. Perbedaan terjadi pada objek yang dikaji pada kedua penelitian, penelitian ini mengkaji objek tuturan ungkapan pemberlakuan Kurikulum 2013, sedangkan penelitian Umami mengkaji objek wacana pojok pada Djaka Lodang.

\section{Bentuk Implikatur yang Mempunyai Maksud Dugaan tentang Kesiapan Siswa}

Implikatur mempunyai maksud dugaan adalah pernyataan penutur untuk menduga tentang sesuatu. Jenis implikatur ini dikategorikan ke dalam fungsi tindak tutur komisif. Berikut contoh implikatur yang menyatakan dugaan pada ungkapan pemberlakuan Kurikulum 2013 di SMK N 8 Surakarta ditunjukkan dengan contoh sebagai berikut:

Percakapan antara peneliti dan guru Matematika di SMK N 8 Surakarta, Kamis, 18 Februari 2016.

"Ya intinya itu lebih banyak ditentukan oleh gurunya, kalau siswa ya menerimalah." 
Konteks percakapan yang terjadi pada contoh (10) mengenai kesiapan dari siswa menerima kurikulum baru. Guru menjelaskan pada tuturan di atas bahwa pada penerapan Kurikulum 2013 lebih ditentukan oleh gurunya. Pada proses pembelajarannya lebih ditentukan oleh guru, guru menerapkan strategi mengajar yang inovatif agar siswa tertarik. Dari segi siswa menurutnya hanya menerima penerapan Kurikulum 2013. Contoh (10) yang menjadi alasan masuk implikatur dugaan yaitu adanya ketidakpastian dalam penjelasan guru terkait dengan kesiapan siswa dalam menerima Kurikulum 2013. Hal itu disampaikan pada tuturan " kalau siswa ya menerimalah". Contoh (10) di atas merupakan bentuk implikatur dugaan tentang kesiapan siswa dalam menerima Kurikulum 2013. Penelitian ini memiliki kesamaan dan perbedaan dengan penelitian terdahulu yaitu penelitian Timur Sri Astami (2014) berjudul "Implikatur Percakapan dalam Film Nihonjin No Shiranai Nihongo". Hasil penelitian menunjukkan implikatur percakapan berupa permintaan, pertanyaan, dugaan, keraguan, kesedihan, sindiran, ejekan, perintah, fakta, dan ajakan terdapat pada film. Perbedaan terjadi pada objek yang dikaji pada kedua penelitian, penelitian ini mengkaji objek tuturan ungkapan pemberlakuan Kurikulum 2013, sedangkan penelitian Astami mengkaji objek Percakapan pada Film.

Percakapan antara peneliti dan guru Bahasa Inggris di SMK N 8 Surakarta, Rabu, 04 Mei 2016.

"Sedangkan kelebihannya siswa atau peserta didik lebih siap menghadapi kemajuan dan perubahan zaman dalam globalisasi dan tuntutan masyarakat Indonesia masa depan.”

Konteks percakapan yang terjadi pada contoh (11) mengenai kekurangan dan kelebihan Kurikulum 2013. Percakapan di atas menjelaskan bahwa Kurikulum 2013 mengembangkan siswa untuk siap menghadapi kemajuan dan perubahan zaman dalm globalisasi dan tuntutan masyarakat masa depan. Pendapat tersebut dikemukakan oleh guru bersangkutan karena Kurikulum 2013 lebih mengedepankan karakter siswa dan siswa bisa mengeksplor diri lebih luas lagi. Contoh (11) yang menjadi alasan masuk implikatur dugaan yaitu tuturan yang disampaikan guru tersebut belum terbukti dengan suatu contoh yang valid, sehingga tuturan tersebut masih dugaan dari guru tersebut. Contoh (11) di atas merupakan bentuk implikatur dugaan tentang kelebihan siswa dalam menerima Kurikulum 2013. Penelitian ini memiliki kesamaan dan perbedaan dengan penelitian terdahulu yaitu penelitian Risalatul Umami (2013) berjudul "Implikatur Percakapan dalam Wacana Pojok pada Djaka Lodang Edisi JanuariJuni Tahun 2013". Hasil penelitian ini disimpulkan bahwa: (1) Implikatur Dhat Nyeng edisi Januari 2013 hingga Juni 2013 menggunakan implikatur sebagai sarana untuk menyatakan sesuatu, menyindir, menanggapi, menghimbau, mengajak, dan mengkritik. Perbedaan terjadi pada objek yang dikaji pada kedua penelitian, penelitian ini mengkaji objek tuturan ungkapan pemberlakuan Kurikulum 2013, sedangkan penelitian Umami mengkaji objek wacana pojok pada Djaka Lodang.

\section{Bentuk Implikatur yang Mempunyai Maksud Keraguan tentang Pelaksanaan Kurikulum 2013}

Percakapan antara peneliti dan guru Bahasa Indonesia di SMK N 8 Surakarta, Jumat, 22 April 2016.

"Sekarang kita bandingkan dengan sekolah swasta, untuk bisa menerapkan Kurikulum 2013 sekolah swasta itu masih memiliki kekurangan, jangankan membiarkan anak untuk mengeksplor diri apa yang diberikan oleh guru, sementara dibimbing oleh guru saja kadang-kadang tidak berjalan." 
Konteks percakapan pada contoh (12) mengenai pemberlakuan Kurikulum 2013. Tuturan pada percakapan di atas menjelaskan bahwa penerapan di sekolah swasta sulit untuk terealisasi karena masih adanya kekurangan di sekolah swasta. Masalah yang ada di sekolah negeri dan sekolah swasta tentunya berbeda, sekolah negeri dibiayai oleh pemerintah sedangkan sekolah swasta untuk dapat memberlakukan Kurikulum 2013 harus dengan dana mandiri, sedangkan sekolah swasta hanya didanai oleh pihak yayasan. Contoh (12) yang menjadi alasan masuk implikatur keraguan yaitu adanya sikap pesimis dari guru ketika Kurikulum diterapkan di sekolah swasta. Alasan yang menjadi dasar yaitu adnya perbedaan antara sekolah negeri dan swasta dari beberapa aspek. Contoh (12) di atas merupakan bentuk implikatur keraguan tentang pelaksanaan Kurikulum 2013. Penelitian ini memiliki kesamaan dan perbedaan dengan penelitian terdahulu, yaitu penelitian Timur Sri Astami (2014) berjudul "Implikatur Percakapan dalam Film Nihonjin No Shiranai Nihongo". Hasil penelitian menunjukkan implikatur percakapan berupa permintaan, pertanyaan, dugaan, keraguan, kesedihan, sindiran, ejekan, perintah, fakta, dan ajakan terdapat pada film. Perbedaan terjadi pada objek yang dikaji pada kedua penelitian, penelitian ini mengkaji objek tuturan ungkapan pemberlakuan Kurikulum 2013, sedangkan penelitian Astami mengkaji objek Percakapan pada Film.

\section{Bentuk Implikatur yang Mempunyai Maksud Kesedihan dalam Mengevaluasi Siswa}

Percakapan antara peneliti dan guru Bahasa Indonesia di SMK N 8 Surakarta, Jumat, 22 April 2016.

"Berbicara kualitas itu relatif ya, karena saya itu malu, antara malu ya sedih. Ya sedih dan malu itu jadi satu."

Konteks percakapan yang terjadi pada contoh (13) yaitu membahas tentang peningkatan kualitas pendidikan setelah diberlakukannya Kurikulum 2013. Dengan diberlakukannya Kurikulum baru tentunya segi kualitas pasti akan ada dampaknya oleh karena itu pada percakapan ini peneliti ingin membahasnya. Segi kualitas menurut guru yang bersangkutan itu sangat relatif bergantung dengan sumber daya yang ada. Guru yang bersangkutan merasa malu, sedih karena segala pelatihan-pelatihan yang dilakukan oleh guru-guru dan berbagai usaha yang dilakukan sekolah pada saat siswa mengerjakan ujian nilai yang dicapai $90 \%$ tidak ada yang tuntas. Akan tetapi, guru juga tidak pesimis tentunya dengan keadaan yang sedemikian guru mengadakan remidial pembelajaran. Pada contoh (13) yang menjadi alasan implikatur yaitu adanya pernyataan kesedihan yang disampaikan oleh guru tersebut. Contoh (13) di atas merupakan bentuk implikatur kesedihan dalam mengevaluasi siswa saat penerapan Kurikulum 2013. Penelitian ini memiliki kesamaan dan perbedaan dengan penelitian terdahulu, yaitu penelitian Risalatul Umami (2013) berjudul "Implikatur Percakapan dalam Wacana Pojok pada Djaka Lodang Edisi Januari-Juni Tahun 2013". Hasil penelitian ini disimpulkan bahwa: (1) Implikatur Dhat Nyeng edisi Januari 2013 hingga Juni 2013 menggunakan implikatur sebagai sarana untuk menyatakan sesuatu, menyindir, menanggapi, menghimbau, mengajak, dan mengkritik. Perbedaan terjadi pada objek yang dikaji pada kedua penelitian, penelitian ini mengkaji objek tuturan ungkapan pemberlakuan Kurikulum 2013, sedangkan penelitian Umami mengkaji objek wacana pojok pada Djaka Lodang.

\section{Bentuk Implikatur yang Mempunyai Maksud Memohon Perubahan Materi}

Percakapan antara peneliti dan guru Matematika di SMK N 8 Surakarta, Kamis, 18 Februari 2016. 
"Jadi seharusnya ya memang Matematika punya kelebihan sendiri-sendiri."

Pada contoh (14) konteks percakapan yang terjadi yaitu peneliti dan guru membahas tentang kekurangan dan kelebihan tengtang Kurikulum 2013. Pada percakapan di atas guru menitik beratkan pada kekurangan yang terjadi di mata pelajaran Matematika. Mata pelajaran Matematika pada Kurikulum 2013 disamakan dari semua program keahlian, baik pariwisata, teknik, ataupun SMA. Lebih lanjut guru yang bersangkutan tidak bisa menerima apabila sistemnya sedemikian, kemudian guru mengatakan memang seharusnya Matematika punya kelebihan sendiri-sendiri. Maksudnya Matematika pada setiap program keahlian memang berbeda dan memiliki kelebihan sendiri-sendiri bukan seperti yang sekarang Matematika dibuat sama semua. Pada contoh (14) yang menjadi alasan implikatur yaitu guru cenderung memohon untuk mata pelajaran Matematika pada Kurikulum 2013 itu dibuat seperti kurikulum lama yang pada tiap program keahlian itu berbeda dan meiliki kelebihan sendiri-sendiri. Contoh (14) di atas merupakan bentuk implikatur memohon perubahan materi pada mata pelajaran Matematika di Kurikulum 2013. Penelitian ini memiliki kesamaan dan perbedaan dengan penelitian terdahulu yaitu penelitian Timur Sri Astami (2014) berjudul "Implikatur Percakapan dalam Film Nihonjin No Shiranai Nihongo". Hasil penelitian menunjukkan implikatur percakapan berupa permintaan, pertanyaan, dugaan, keraguan, kesedihan, sindiran, ejekan, perintah, fakta, dan ajakan terdapat pada film. Perbedaan terjadi pada objek yang dikaji pada kedua penelitian, penelitian ini mengkaji objek tuturan ungkapan pemberlakuan Kurikulum 2013 sedangkan penelitian Astami mengkaji objek Percakapan pada Film.

\section{SIMPULAN}

Simpulan dari pembahasan di atas sebagai berikut. Bentuk implikatur percakapan pada ungkapan pemberlakuan kurikulum 2013 di SMK N 8 Surakarta meliputi implikatur yang mempunyai maksud memberitahu, implikatur yang mempunyai maksud mengeluh, implikatur yang mempunyai maksud menanya, implikatur yang mempunyai maksud menyindir, implikatur yang mempunyai maksud dugaan, implikatur yang mempunyai maksud keraguan, implikatur yang mempunyai maksud kesedihan, implikatur yang mempunyai maksud memohon.

\section{DAFTAR PUSTAKA}

Cummings, Louise. 2007. Pragmatik: Sebuah Perspektif Multidisipiner. Yoyakarta: Pustaka Pelajar.

Rahardi, Kunjana. 2007. Pragmatik: Kesantunan Imperatif Bahasa Indonesia. Jakarta: Erlangga.

Rani, Abdul. Dkk. 2006. Analisis Wacana Sebuah Kajian Bahasa Dalam Pemakaian. Malang: Bayumedia Publishing.

Rohmadi, Muhammad. Pragmatik: Teori dan Analisis. Surakarta: Yuma Pustaka.

Sri Astami, Timur. 2014. "Implikatur Percakapan dalam Film Nihonjin No Shiranai Nihongo". Humaniora. Vol. 05, No. 02, halaman 1271-1278. Diakses pada tanggal 28 Oktober 2015 di laman http//scholar.google.co.id.

Sudaryanto. 2015. Metode dan Aneka Teknik Analisis Bahasa. Yogyakarta: Sanata Dharma University Press.

Sugiyono. 2012. Metode Penelitian Kuantitatif, Kualitatif, dan R\&D. Bandung: Penerbit Alfabeta.

Utami, Risalatul. 2013. “Implikatur Percakapan dalam Wacana Pojok pada Djaka Lodang 
Edisi Januari-Juni Tahun 2013". Jurnal Pendidikan, Bahasa, Sastra, dan Budaya Jawa Universitas Muhammadiyah Purworejo. Vol. 03, No. 02, halaman 47-51. Diakses pada tanggal 28 Oktober 2015 di laman http//scholar.google.co.id.

Wijana, I Dewa Putu. 1996. Dasar-dasar Pragmatik. Yogyakarta: Andi Offset.

Wijana, I Dewa Putu dan Muhammad Rohmadi. 2009. Analisis Wacana Pragmatik Kajian Teori dan Analisis. Surakarta: Yuma Pustaka.

Yule, Goerge. 2006. Pragmatik. Yogyakarta: Pustaka Pelajar 